九州大学学術情報リポジトリ

Kyushu University Institutional Repository

Sugar Accumulation Types among Acid Citrus as might be Proposed by Seasonal Changes in Reducing and Non-reducing Sugar Ratios in the Juice

Widodo, Soesiladi E.

Fruit Science Laboratory, Faculty of Agriculture, Kyushu University

Shiraishi, Mikio

Fruit Science Laboratory, Faculty of Agriculture, Kyushu University

Shiraishi, Shinichi

Fruit Science Laboratory, Faculty of Agriculture, Kyushu University

https://doi.org/10.5109/24097

出版情報 : 九州大学大学院農学研究院紀要. 40 (1/2)，pp.93-103，1995-12. Kyushu University バージョン：

権利関係 : 


\title{
Sugar Accumulation Types among Acid Citrus as might be Proposed by Seasonal Changes in Reducing and Non-reducing Sugar Ratios in the Juice
}

\author{
Soesiladi E. Widodo, Mikio Shiraishi and Shinichi Shiraishi \\ Fruit Science Laboratory, Faculty of Agriculture, \\ Kyushu University, Fukuoka 81 1-23, Japan \\ (Received July 26, 1995)
}

\begin{abstract}
In order to know if there is any differences in sugar accumulation pattern among acid citrus, the present experiment was preliminary carried out using Hanayu (Citrus hanayu Hort. ex Shirai, designated as H), Kabosu (C.sphaerocarpa Hort. ex Tanaka, designated as K), Sudachi (C.sudachi Hort. ex Shirai designated as S), 'Lisbon' lemon (C. limon Burm. f. Lisbon, designated as L), Yuzu(C. junos Sieb. ex Tanaka, designated as Y) and some of their F-1 progenies. Seasonal changes in sugars and acids of these citrus were examined along with some physical fruit characteristics. If focussed to reducing sugar (RS)-to-non-reducing sugar (NonRS) ratios in the juice, it seems there are 3 types among them, namely Non-RS Type I, Non-RS Type II and RS Type. K, S and H X Y 16 seemed to belong to Non-RS Type I, H and H X K 25 to Non-RS Type II, and L, Y, S X K 25 and L $\times$ Y 34 to RS Type. The ratios specifically assigned to each group seemed to be a good indicator of fruit, maturity for the acid citrus if only juice quality is taken into account.
\end{abstract}

\section{INTRODUCTION}

To increase the flavor of cultivated tomato (Lycopersicon esculentum) which is a reducing sugar (RS) accumulating type (it accumulates predominantly glucose and fructose), the wild tomato species such as L. chmielewskii and L. hirsutum which are non-reducing sugar (Non-RS) accumulating types (they characteristically store sucrose), are used in tomato breeding programs as donor parents (Stommel and Haynes, 1993; Yelle et al., 1991). Accordingly, the enzymes responsible for differentiating the RS and Non-RS accumulators have been intensively studied recently (Manning and Maw, 1975; Miron and Schaffer, 1991; Ohyama et al., 1995; Stommel, 1992; Yelle et al., 1988). Meanwhile, sugar accumulation was known to be a heritable factor in tomato (Stommel and Haynes, 1993; Yelle et al., 1991) and in carrot (Freeman and Simon, 1983). Those indicate that knowing the sugar accumulating type is very important in breeding programs for an increased juice flavor quality.

RS and Non-RS accumulating types have been detected in tomatos (Davies, 1966; Manning and Maw, 1975; Miron and Schaffer, 1991; Ohyama et al., 1995; Stommel, 1992; Yelle et al., 1988), persimmon (Diospyros kaki) cultivars (Guo and Sugiura, 1990), and sugarcane (Hatch and Glasziou, 1963). In citrus, oranges (Harding et al., 1940) and Satsuma mandarins (Citrus unshiu Marc.) (Daito and Sato, 1985) seem to be Non-RS accumulators as they accumulate sucrose during fruit maturation, whereas lemons (Sinclair, 1984) and grapefruit (Hilgeman and Smith, 1940; Sinclair, 1972) should be RS accumulators since the RS content is generally higher than the Non-RS one. No information on the sugar accumulation types of Japanese acid citrus, however, is available. 
Of many Japanese acid citrus, Yuzu (C. junos Sieb. ex Tanaka), Kabosu (C. sphaerocarpa Hort. ex Tanaka), Sudachi (C. sudachi Hort. ex Shirai), and Hanayu (C. hanayu Hort. ex Shirai) are known for their high acidity and fragrance. From biochemical and enzymatic studies (Berhow et al., 1994; Hashinaga and Hasegawa, 1989; Hirai et al., 1986; Ohta et al., 1992; Ozaki et al., 1991; Rouseff and Nagy, 1982), they have been strongly suspected to be hybrids related to, at least, Ichang papeda (C. ichangensis) or Ichang lemon (C. wilsonii) as one of their suspected parents. Variabilities in sugar accumulation in their juice may then be expected. Stommel and Simon (1989) found variabilities in sugar accumulation among populations of carrot (Daucus carota L.) inbred lines.

The present study reports differences in sugar accumulation patterns among acid citrus, and seasonal changes of juice qualities and some physical fruit characteristics in order to see if there is any connection between sugar accumulation patterns and fruit maturation. Hilgeman and Smith (1940) proposed a somewhat low point of RS-to-Non-RS ratio as an index of maturity in grapefruit.

\section{MATERIALS AND METHODS}

The parent acid citrus investigated were Hanayu (Citrus hanayu), Kabosu (C. sphaerocarpa), Sudachi (C. sudachi), 'Lisbon' lemon (C. limon), and Yuzu (C. junos) . The F-l progenies investigated were those of Hanayu X Kabosu, Hanayu $\times$ Yuzu, Sudachi $\mathrm{X}$ Kabosu and Lisbon X Yuzu; the first capital letters of parent names are, hereafter, used to designate the parent and progeny names. In all cases of the progeny names the female parent is mentioned first. The progenies were budded on Satsuma mandarin (C. unshiu Marc.). The progenies were chosen to represent the expected combinations of the sugar accumulation types. Sugar accumulation type was found to be a heritable character in tomato (Yelle et al., 1991; Stommel and Haynes, 1993) and carrot (Freeman and Simon, 1983).

The fruits were tagged when they were about $1 \mathrm{~cm}$ in diameter. Ten fruits were monthly sampled from September 16, 1994 to December 16, 1994 from parent and F-1 progeny trees grown in the Fruit Trees Experiment Station (FTES) of Kyushu University at Sasaguri, Fukuoka, Japan. The fruits of Sudachi were monthly sampled from the Fukuoka Agricultural Research Center (FARC) at Chikushino, Fukuoka, Japan. As a consequence of location effect that might bias the groupings, the fruits of Kabosu and Yuzu were sampled in both stations at the same sampling dates. It was conducted merely to show the location effect in connection with the RS and Non-RS groupings. The fruits were quickly carried to our laboratory, and were once kept refrigerated. Measurement of physical fruit characteristics and juice extraction were accomplished within 1-3 days after sampling.

The diameter and height of the fruits were measured to calculate fruit shape index (diameter/height). The fruits were individually weighed and peeled. The juice of each fruit was extracted with hand-pressed juicer, and weighed. The combined juice of 10 fruits was'centrifuged at 2,500 rpm for 20 minutes. About $100 \mathrm{ml}$ of the supernatant was quickly freezed for analyses. 
Reducing sugar content was determined by a modified procedure of Bertrand's method (1906) which is already used by Shiraishi (1993). Total sugar content was determined as follows: $4 \mathrm{ml}$ of deionized water was added to $1 \mathrm{ml}$ juice, and then $5 \mathrm{ml}$ of $4 \% \mathrm{H}_{2} \mathrm{SO}_{4}$ was added into it. The solution was boiled for 30 minutes, and was neutralized with $2 \mathrm{~N} \mathrm{NaOH}$. This solution was then treated the same as in the reducing sugar determination. The non-reducing sugar content was the difference between total and reducing sugar contents.

Free acid content (titratable acidity) was determined by a titration with $0.1 \mathrm{~N} \mathrm{NaOH}$ and phenolphthalein as indicator. The titrated solution was then passed through a column $(1.6 \mathrm{~cm} \mathrm{I}$. D. X $4 \mathrm{~cm})$ of cation-exchange resin Amberlite IR-120 and its total acid content was determined the same as in the determination of free acid content.

\section{RESULTS AND DISCUSSION}

As shown in Table 1, locations affected greatly sugar and acid contents of Kabosu and Yuzu. This effect was observed as a delay of phase change from RS to Non-RS accumulator in Kabosu, but it did not affect the groupings (Table 2). It seems that location affects the phase change followed by a delay of harvest time, but does not affect the groupings to which a given citrus species belongs.

Table 2 shows the reducing sugar (RS) and non-reducing sugar (Non-RS) ratios of the acid citrus examined and a possible grouping resulted from the ratios. The acid citrus examined might be grouped into three types: Non-RS Type I characterized by having a phase change from a RS accumulator to a Non-RS accumulator (Kabosu of the FTES and Sudachi around Nov./Dec., H X Y 16 around Oct.Nov.), Non-RS Type II characterized by relatively high portions of non-reducing sugar during maturation without a marked phase change (Hanayu and H X K 25) and RS Type ('Lisbon', Yuzu, S X K 25 and L X Y 34) characterized by relatively high portions of reducing sugar and having a minimum or maximum point in a certain moment during fruit maturation.

Table 1. Seasonal changes in acid and sugar contents ( $\mathrm{mg} / \mathrm{ml}$ ) of Kabosu and Yuzu from different locations, 1994.

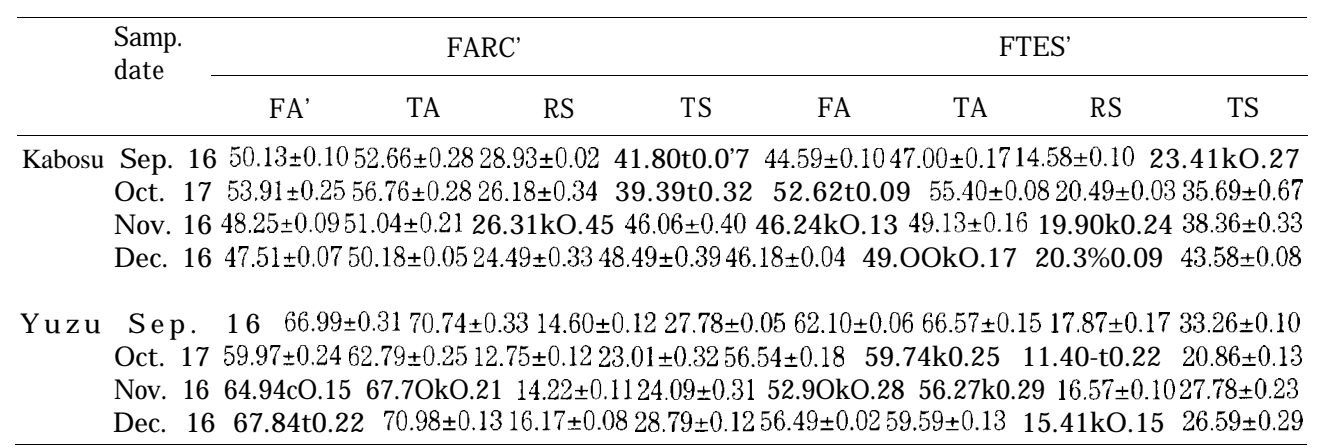

'FARC=Fukuoka Agricultural Research Center; FTES=Fruit Trees Experiment Station of Kyushu University. "FA, TA, RS and TS are free acid, total acid, reducing sugar and total sugar, respectively; Mean \pm S.E. 
Table 2. Reducing and non-reducing sugar ratios of sugar accumulation types among acid citrus.

\begin{tabular}{|c|c|c|c|c|}
\hline Citrus & Samp. date & & RS/Non-RS & Group \\
\hline Kabosu (K)" & $\begin{array}{l}1994 / 09 / 16 \\
1994 / 10 / 17 \\
1994 / 11 / 16 \\
1994 / 12 / 16\end{array}$ & $\begin{array}{l}1.65 \\
1.35 \\
1.08 \\
0.88\end{array}$ & $\begin{array}{l}(62.28: 37.72) \\
(57.41: 42.59) \\
(51.89: 48.11) \\
(46.76: 53.24)\end{array}$ & Non-RS Type I \\
\hline Kabosu (K) & $\begin{array}{l}1994 / 09 / 16 \\
1994 / 10 / 17 \\
1994 / 11 / 16 \\
1994 / 12 / 16\end{array}$ & $\begin{array}{l}2.25 \\
1.98 \\
1.33 \\
1.04\end{array}$ & $\begin{array}{l}(69.21: 30.79) \\
(66.47: 33.53) \\
(57.11: 42.89) \\
(51.06: 48.94)\end{array}$ & Non-RS Type I \\
\hline Sudachi (S) & $\begin{array}{l}1994 / 09 / 16 \\
1994 / 10 / 17 \\
1994 / 11 / 16 \\
1994 / 12 / 16\end{array}$ & $\begin{array}{l}2.12 \\
1.25 \\
1.01 \\
0.96\end{array}$ & $\begin{array}{l}(67.99: 32.01) \\
(55.52: 44.48) \\
(50.23: 49.77) \\
(48.92: 51.08)\end{array}$ & Non-RS Type I \\
\hline $\mathrm{H} \times \mathrm{Y} 16$ & $\begin{array}{l}1994 / 09 / 16 \\
1994 / 10 / 17 \\
1994 / 11 / 16 \\
1994 / 12 / 16\end{array}$ & $\begin{array}{l}1.49 \\
1.29 \\
0.91 \\
0.64\end{array}$ & $\begin{array}{l}(59.90: 40.10) \\
(56.30: 43.70) \\
(47.75: 52.25) \\
(38.97: 61.03)\end{array}$ & Non-RS Type I \\
\hline Hanayu (H) & $\begin{array}{l}1994 / 09 / 16 \\
1994110117 \\
1994 / 11 / 16 \\
1994 / 12 / 16\end{array}$ & $\begin{array}{l}0.38 \\
0.48 \\
0.37 \\
0.70\end{array}$ & $\begin{array}{l}(27.36: 72.64) \\
(32.33: 67.67) \\
(26.80: 73.20) \\
(41.17: 58.83)\end{array}$ & Non-RS Type II \\
\hline HXK25 & $\begin{array}{l}1994 / 09 / 16 \\
1994 / 10 / 17 \\
1994111 / 16 \\
1994 / 12 / 16\end{array}$ & $\begin{array}{l}0.83 \\
0.70 \\
0.53 \\
0.64\end{array}$ & $\begin{array}{l}(45.40: 54.60) \\
(41.23: 58.77) \\
(34.56: 65.44) \\
(38.96: 61.04)\end{array}$ & Non-RS Type II \\
\hline Yuzu (Y)" & $\begin{array}{l}1994109116 \\
1994 / 10 / 17 \\
1994 / 11 / 16 \\
1994 / 12 / 16\end{array}$ & $\begin{array}{l}1.16 \\
1.20 \\
1.48 \\
1.38\end{array}$ & $\begin{array}{l}(53.76: 46.24) \\
(54.65: 45.35) \\
(59.65: 40.35) \\
(57.96: 42.04)\end{array}$ & RS Type \\
\hline Y̌uzu (Y) & $\begin{array}{l}1994 / 09 / 16 \\
1994110117 \\
1994 / 11 / 16 \\
1994 / 12 / 16\end{array}$ & $\begin{array}{l}1.11 \\
1.24 \\
1.44 \\
1.28\end{array}$ & $\begin{array}{l}(52.57: 47.43) \\
(55.40: 44.60) \\
(59.03: 40.97) \\
(56.17: 43.83)\end{array}$ & RS Type \\
\hline Lisbon (L) & $\begin{array}{l}1994109116 \\
1994 / 10 / 17 \\
1994111116 \\
1994 / 12 / 16\end{array}$ & $\begin{array}{l}1.60 \\
1.61 \\
1.40 \\
1.09\end{array}$ & $\begin{array}{l}(61.50: 38.50) \\
(61.71: 38.29) \\
(58.28: 41.72) \\
(52.20: 47.80)\end{array}$ & RS Type \\
\hline SXK25 & $\begin{array}{l}1994 / 09 / 16 \\
1994 / 10 / 17 \\
1994 / 11 / 16 \\
1994112116\end{array}$ & $\begin{array}{l}2.02 \\
1.45 \\
1.27 \\
1.36\end{array}$ & $\begin{array}{l}(66.92: 33.08) \\
(59.12: 40.88) \\
(55.99: 44.01) \\
(57.57: 42.43)\end{array}$ & RS Type \\
\hline LXY34 & $\begin{array}{l}1994 / 09 / 16 \\
1994 / 10 / 17 \\
1994 / 11 / 16 \\
1994 / 12 / 16\end{array}$ & $\begin{array}{l}2.22 \\
2.46 \\
3.23 \\
2.61\end{array}$ & $\begin{array}{l}(68.93: 31.07) \\
(71.07: 28.93) \\
(76.36: 23.64) \\
(72.33: 27.67)\end{array}$ & RS Type \\
\hline
\end{tabular}

"Sample from the Fruit Trees Experiment Station of Kyushu University. 'Sample from the Fukuoka Agricultural Research Center.

'Reducing sugar (RS): Non-reducing sugar (Non-RS) ratios as \% of total. 

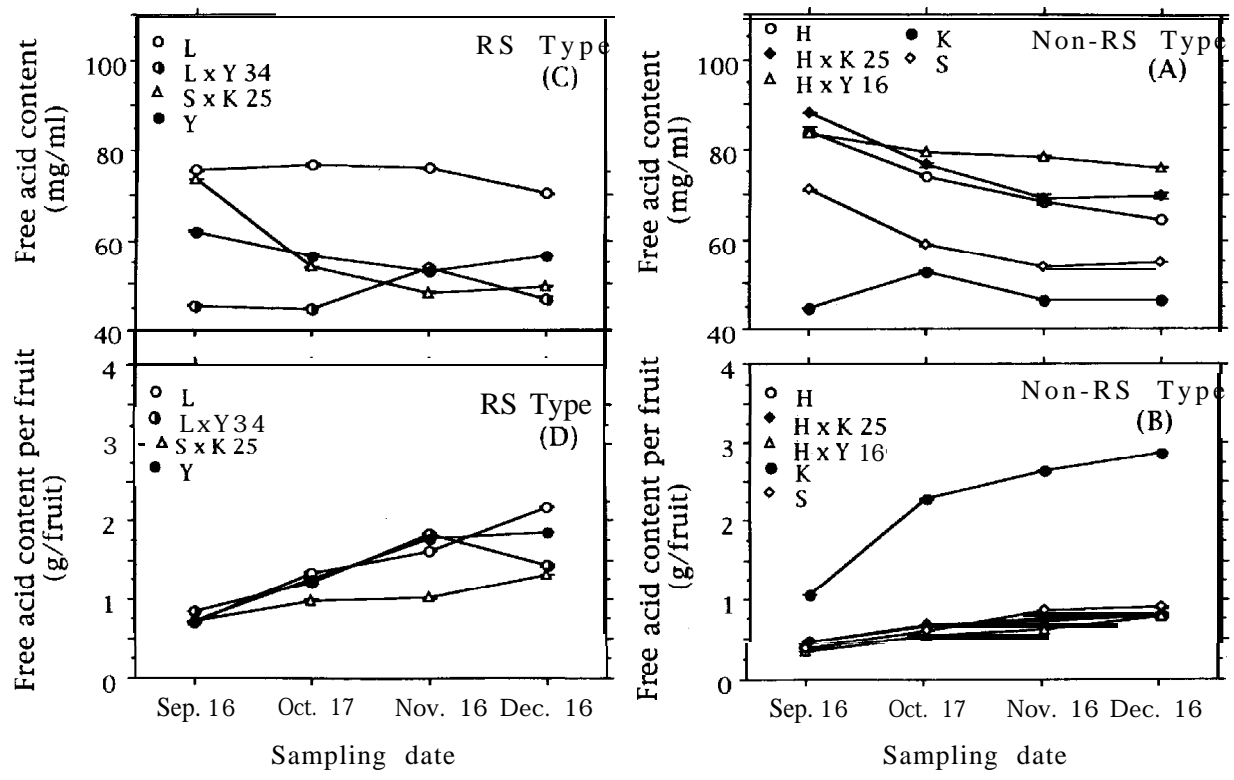

Fig. 1. Seasonal changes in absolute acidity and acidity per fruit of non-reducing (Non-RS) and reducing sugar (RS) typed acid citrus. H, K, Y, S and L are designated for Hanayu, Kabosu, Yuzu, Sudachi and 'Lisbon' lemon, respectively. Number after progeny names is the progeny's number. Bars represent standard errors.
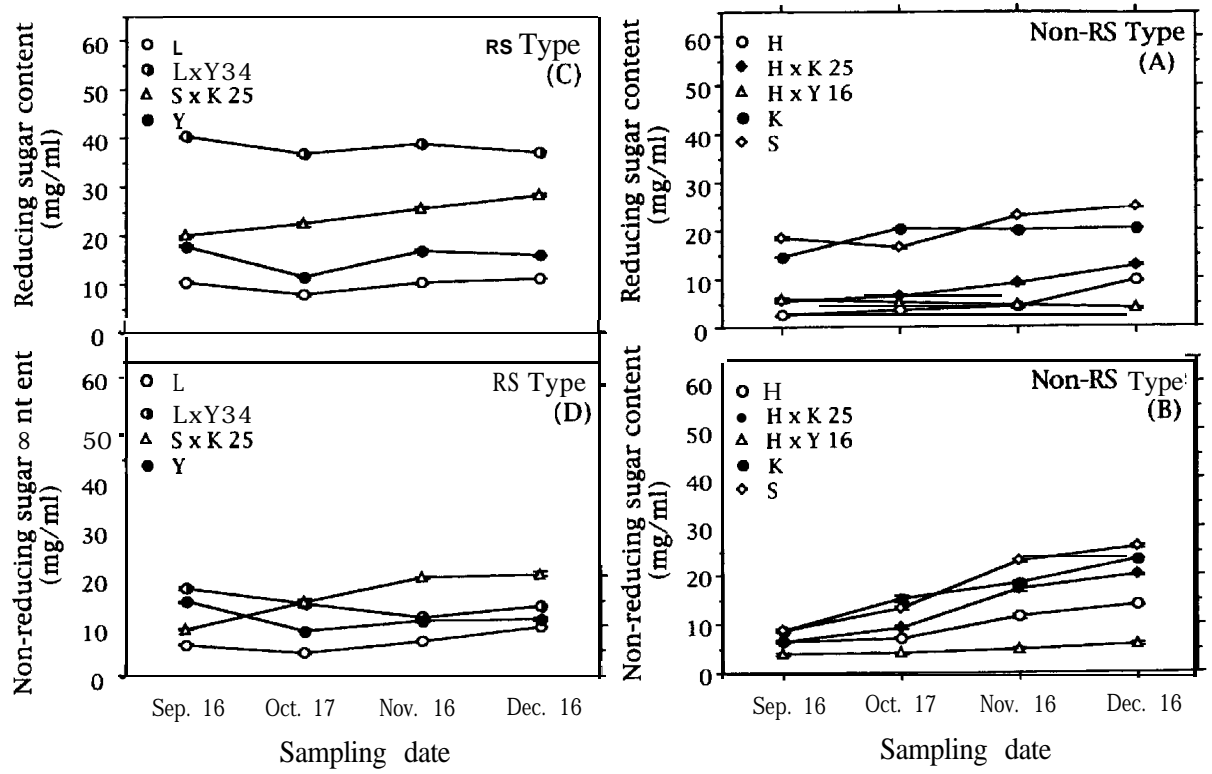

Fig. 2. Seasonal changes in sugar contents of non-reducing sugar (Non-RS) and reducing sugar (RS) typed acid citrus. See notes in Fig. 1. 

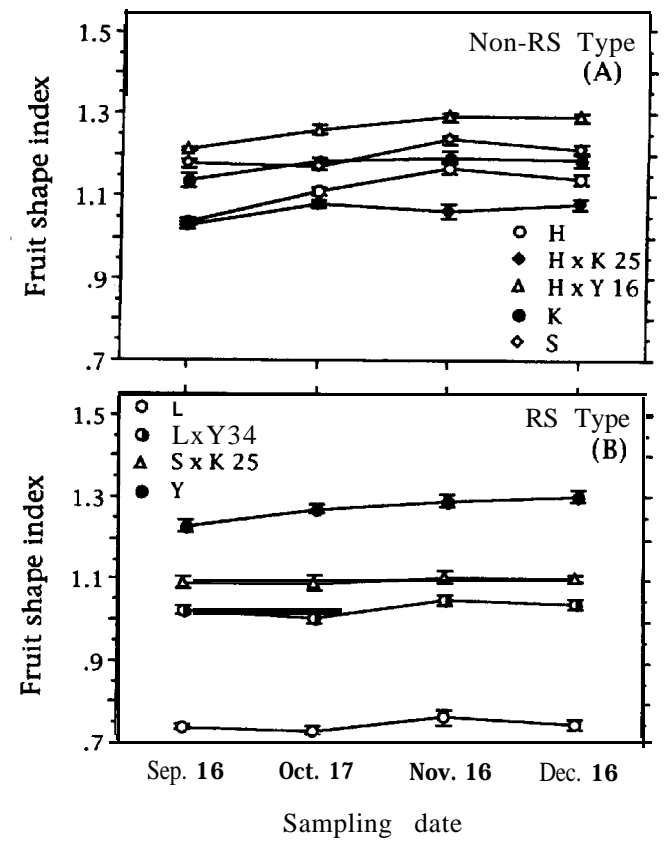

Fig. 3. Seasonal changes in fruit shape index of nonreducing (Non-RS) and reducing sugar (RS) typed acid citrus. See notes in Fig. 1.

The groupings were not clear by acidity (Fig. 1) and sugar components (Fig. 2). In general, acidity was decreasing while sugar content was increasing as the fruits increased in weight. A somewhat different pattern was observed through fruit shape index (Fig. 3). The RS Type tended to keep the index constant during fruit growth as was also observed in lemon (McDonald and Hillebrand, 1980), while Non-RS Type changed it larger until November 16. However, to correlate the groupings to this index seems too risky, because cultural practices and low night temperatures have been shown to produce more elongated fruits (Embleton et al., 1967; Wutscher, 1976).

Fig. 4 was drawn to show seasonal changes in relative sourness among the acid citrus investigated. In general, the ratio is decreasing during maturation. However, more attention should be paid to Hanayu and $\mathrm{H} \times \mathrm{K} 25$, which belong to Non-RS Type II. The reason is that their ratios decreased sharply in comparison with slower rates of the NonRS Type I and RS Type. Sugars, both kind and amount, are known to contribute to fruit and vegetable flavor (Freeman and Simon, 1983; Yelle et al., 1991; Stommel, 1992; Moriguchi et al., 1992). Therefore, the ratio in Fig. 4 will indirectly tell about the relative overall flavor. In other words, the overall relative flavor of the juice of Non-RS Type II will be greatly decreased during fruit maturation. These differences support separation within the Non-RS Type into Type I and Type II.

Here arises a question whether these groupings can be meaningful or not on a determination of fruit maturity. In this connection, some brief discussions will be tried as 

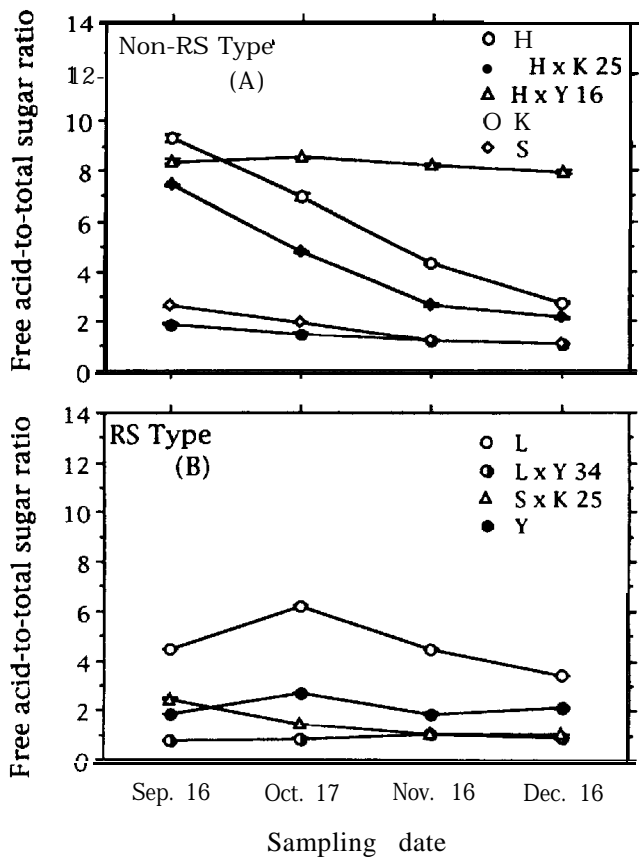

Fig. 4. Seasonal changes in free acid-to-total sugar ratios of non-reducing (Non-RS) and reducing sugar (RS) typed acid citrus. See notes in Fig. 1.

follows in accordance with the three types proposed.

\section{Non-RS Type I}

Kabosu, which is widely cultivated at Oita Prefecture, Japan, is the so-called green 'sour orange'. The fruit is preferably harvested in a green stage around SeptemberOctober due to its quick natural degreening and loss of flavor (Murata, 1982; Yamauchi et c-cl., 1991). Our data show that in September both free acid content (Fig. 1, A) and juice weight (Fig. 5, A) of Kabosu were still low, and consequently free acid content per fruit was low (Fig. 1, B). A marked increase in free acid content in October (Fig. 1, A and B) along with a sharp increase in juice and fruit weights (Fig. 5, A and B) might be used to be an indicator of fruit maturity of Kabosu. Its juice weight (Fig. 5, A), however, was still increasing up to November and the decrease of its sourness was the slowest (Fig. 4, A). From these data, a high juice quality of Kabosu may still be expected up to November or even to December without worrying about the loss of its juice sourness or juice flavor. This is, interestingly, matched with its phase change around November/December (Table 2). The same is true for Sudachi and H X Y 16 (Table 2) which belong to this group. It should be mentioned, however, Kabosu and Sudachi are highly priced in Japan only when they are green, eventhough their juice quality may not be high at that time. For example, the harvesting time of Sudachi has long been decided to be in September because the quantity of its essential oil in the peel was found to be high in September (Waki and 

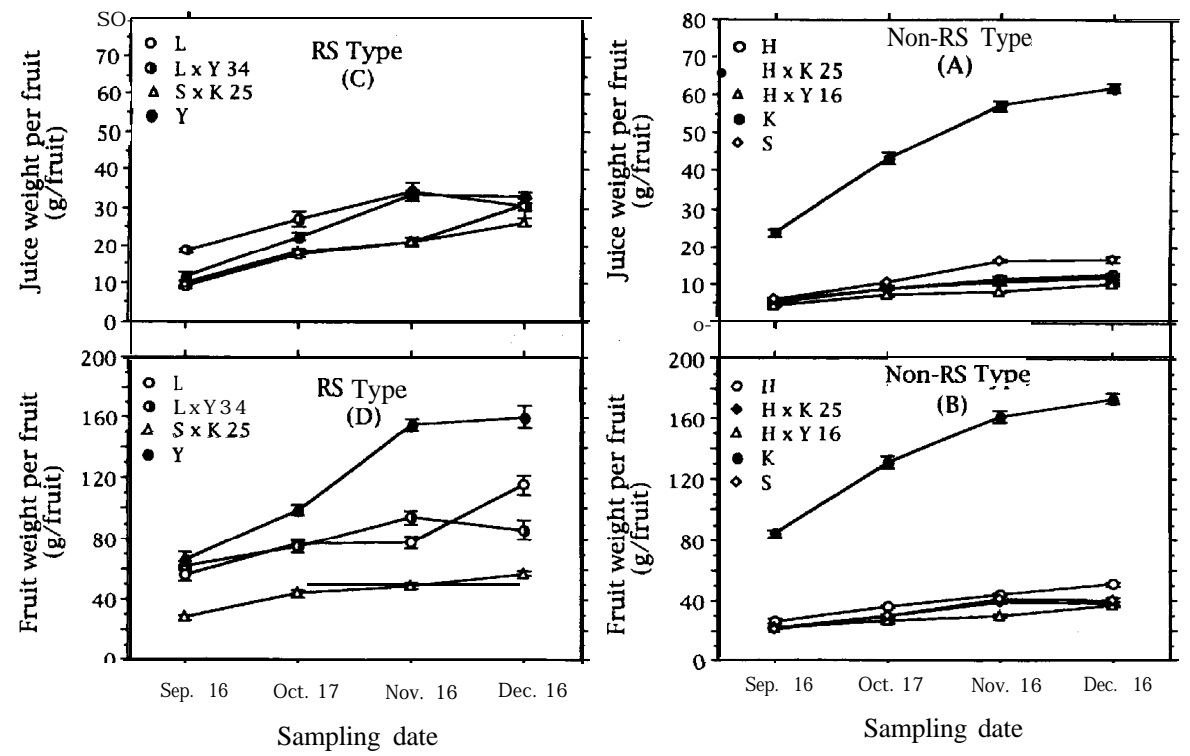

Fig. 5. Seasonal changes in juice and fruit weights of non-reducing (Non-RS) and reducing sugar (RS) typed acid citrus. See notes in Fig. 1.

Nakanishi, 1967), eventhough the acid content of its juice in September was less than half of that in November (Waki, 1959).

\section{Non-RS Type II}

This is the type to which more attention should be paid in determining maturity not only because there is no phase change detected as in the Non-RS Type I but also because its fruit juice is characterized by a sharp decrease in sourness or overall flavor (Fig. 4, A). Its juice flavor sharply decreased (Fig. 4, A) due to a sharp decrease in free acid content (Fig. 1, A) and a sharp increase in non-reducing sugar content (Fig. 2, B). Meanwhile, its juice and fruit weights increased slowly (Fig. 5, A and B). As there is no single indicator from the RS-to-Non-RS ratio, fruit color is the only indicator. The harvest season of Hanayu has been stated around December (Yamaki, 1988) when its fruit color has apparently reached a yellow stage. Our data suggest, however, that growers and consumers should be aware of decreased juice flavor during fruit maturation of Hanayu.

\section{RS Type}

RS Type is different from Non-RS Type II eventhough maintaining a high reducing sugar content during maturation. As to this group there is a high or low point on the RS/Non-RS ratio which differs depending on the species (Table 2). Similar to the Non-RS Type I, the point generally coincides with high free acid content per fruit (Fig. 1, D) due to high juice weight (Fig. 5, C) without worrying about loss of overall flavor (Fig. 4, B). The point, which in this study was generally around November, will be good enough to be an indicator of fruit maturity. The harvest season of Yuzu has been stated around 
December (Yamaki, 1988). Hilgeman and Smith (1940) actually proposed a somewhat low point of RS/Non-RS ratio as an index of maturity.

The biochemical basis for differentiation in the three sugar accumulation types proposed is related to the mechanism of sugar accumulation. It is almost certain that an increase in the activities of sucrose-phosphate synthase (SPS) and/or sucrose synthase (SS) leads to sucrose accumulation (Cordenunsi and Lajolo, 1995; Giaquinta, 1979; Hubbard et al., 1989; Miron and Schaffer, 1991; Moriguchi et al., 1992; Stommel, 1992). Whether a decline in the activity of acid invertase is obsolutely required for sucrose accumulation or not is still in argument (see Giaquinta, 1979; Hubbard et al., 1989; Miron and Schaffer, 1991; Moriguchi et al., 1992; Stommel, 1992; Yelle et al., 1991). High activity of acid invertase, however, has been shown to prevent sucrose accumulation (Ohyama et al., 1995). Therefore, an increase in the activities of SPS, SS, and/or a decrease in the activity of acid invertase hypotetically characterize the Non-RS Types of the acid citrus investigated, and a high-level activity of acid invertase might be responsible for reducing sugar accumulation in the RS Type. Both alkaline and acid invertases are present in Satsuma mandarin (C. unshiu Marc.), and a decline in the activity of acid invertase has promoted its sucrose accumulation (Kato and Kubota, 1978).

As shown here, differences in sugar accumulation patterns are likely to exist even in acid citrus. By knowing which group they belong to, in addition to the other existing indicators such as total soluble solid-to-acid ratio, fruit maturity related to juice quality can be predicted objectively. More distinct characteristics will be expected a lot since research in flavor is developing by more sophisticated techniques and apparatus.

Our other data seem to indicate that there is an inheritance pattern of sugar accumulation. Sugar accumulation was known to be a heritable factor in tomato (Stommel and Heynes, 1993; Yelle et al., 1991) and carrot (Freeman and Simon, 1983), controlled by a single gene dominant for a high percentage of RS. Furthermore, there have been some efforts to correlate sugar accumulation to cold hardiness (Parker, 1959 and 1962; Sakai, 1960 and 1966; Siminovitch et al., 1953; Sieckmann and Boe, 1978; Li et al., 1964) along with its conflicting results (Fuchigami et al., 1973; Lasheen and Chaplin, 1977).

\section{ACKNOWLEDGEMENTS}

The authors wish to thank Dr. Akira Wakana of the Fruit Trees Experiment Station of Kyushu University, Sasaguri, Fukuoka and Mr. Yoshiki Oba of the Fukuoka Agricultural Research Center, Chikushino, Fukuoka, Japan for the fruits used in this study.

\section{REFERENCES}

Berhow, M. A., M. Omura, H. Ohta, Y. Ozaki, and S. Hasegawa 1994 Limonoid in seeds of three citrus hybrids related to Citrus ichangensis. Phytochemistry, 36(4): 923-925

Bertrand, G. 1906 The determination of reducing sugars. Bull. Assoc. Chim. Sucr Dist., 24: 1017-1030

Cordenunsi, B. R. and F. M. Lajolo 1995 Starch breakdown during banana ripening: sucrose synthase and sucrose phosphate synthase. J.Agric. Food Chem., 43: 347-351

Daito, H. and Y. Sato 1985 Changes in the sugar and organic acid components of Satsuma mandarin fruit during maturation. J.Japan.Soc.IIort.Sci.,54(2):155-162 (in Japanese, with English summary) 
Davies, J. N. 1966 Occurrence of sucrose in the fruit of some species of Lycopersicon. Nature, 209: 640641

Embleton, T. W., W. W. Jones and A. L. Page 1967 Potassium and phosphorus effects on deficient Eureka lemon trees and some salinity problems. Proc.Amer. Soc. Hort. Sri., 91 : 120-127

Freeman, R. E. and P. W. Simon 1983 Evidence for simple genetic control of sugar type in carrot (Daucuscarota L.). J.Amer.Soc. Hort.Sci., 108(1): 50-54

Fuchigami, L. H., C. J. Weiser and D. G. Richardson 1973 The influence of sugar on growth and cold acclimation of excised stems of Red-Osier Dogwood. J.Amer.Soc.Hort.Sci, 98(5): 444-447

Giaquinta, R. T. 1979 Sucrose translocation and storage in the sugar beet. Plant Plyysiol., 63: 828-832

Guo, H. Z. and A. Sugiura 1990 Changes in sugar composition in relation to invertase activity in the growth and ripening of persimmon (Diospyroskaki) fruits. J.Japan.Soc.Hort.Sci.,59(2): 281-287 (in Japanese, with English summary)

Harding, P. L., J. R. Winston and D. F. Fisher 1940 Seasonal changes in Florida oranges. U.S.Dept.Agr. Tech.Bull., 753: 1-89

Hashinaga, F. and S. Hasegawa 1989 Limonoids in seeds of sudachi (Citrus sudachi Hort. ex Shirai). J. Japan. Soc. Hot?. Sci.,58(1): 227-229 (in Japanese, with English summary)

Hatch, M. D. and K. T. Glasziou 1963 Sugar accumulation cycle in sugarcane. II. Relationship of invertase activity to sugar content and growth rate in storage tissue of plants grown in controlled environments. Plant Physiol., 38: 344-348

Hilgeman, R. H. and J. G. Smith 1940 Changes in invert sugar and sucrose during ripening of Arizona grapefruit. Proc.Amer.Soc.Hort. Sri., 37: 535-538

Hirai, M., I. Kozaki, and I. Kajiura 1986 Isozyme analysis and phylogenic relationship of citrus. Japan.J. Breed.,36: 377-389

Hubbard, N.L., S. C. Huber and D. M. Pharr 1989 Sucrose phosphate synthase and acid invertase as determinants of sucrose concentration in developing muskmelon (Cucumismelo L.) fruits. Plant Physiol., 91: 1527-1534

Kato, T. and S. Kubota 1978 Properties of invertases in sugar storage tissues of citrus fruit and changes in their activities during maturation. Physiol.Plam ., 42: 67-72

Lasheen, A. M. and C. E. Chaplin 1977 Seasonal sugar concentration in two peach cultivars differing in cold hardiness. J.Amer. Soc.Hort.Sci., 102(2): 171-174

Li, P. H., C. J. Weiser and R. van Huystee 1964 Changes in metabolites of Red-Osier Dogwood during cold hardiness. J. Amer. Soc. Hort. Sci., 86: 723-730

Manning, K. and G. A. Maw 1975 Distribution of acid invertase in the tomato plant. Phytochemistry, 14: 1965-1969

McDonald, R. E. and B. M. Hillebrand 1980 Physical and chemical characteristics of lemons from several countries. J.Amer. Soc:Hort.Sei., 105(1): 135-141

Miron, D. and A. A. Schaffer 1991 Sucrose phosphate synthase, sucrose synthase, and invertase activities in developing fruit, of Lycopersiconesculentum Mill. and the sucrose accumulating Lycopersicon hirsutum Humb. and Bonpl. Plant Physiol., 95: 623-627

Moriguchi, T., K. Abe, T. Sanada and S. Yamaki 1992 Levels and role of sucrose synthase, sucrose-phosphate synthase, and acid invertase in sucrose accumulation in fruit of Asian pear. J.Amer. Soc. Hort. Sri., 117(2): 274-278

Murata, T. 1982 Effect of temperature on the physiological changes of Kabosu (Citmus sphaerocarpa Hort. ex Tanaka) fruit during storage. J.Japan.Soc.Hort. Sci., 50(4): 516-520 (in Japanese, with English summary)

Ohta, H., M. Berhow, R. D. Bennett, and S. Hasegawa 1992 Limonoids in seeds of Citrus hanaju. Phytochemistry, 31(11): 3905-3907

Ohyama, A., H. Ito, T. Sato, S. Nishimura, T. Imai and M. Hirai 1995 Supression of acid invertase activity by antisense RNA modifies the sugar composition of tomato fruit. Plant ('ell Physiol.,36(2): 369-376

Ozaki, Y., M. Miyake, H. Maeda, Y. Ifuku, R. D. Bennett, Z. Herman, C. H. Fong, and S. Hasegawa 1991 Ichangensin glucoside in Citrus junos, Citrus sudachi and Citrus sphaerocarpa. Phytochernistry, 30(8): 2659-2661

Parker, J. 1959 Seasonal changes in white pine leaves: a comparison of cold resistance and free-sugar fluctuations. Bot.Gaz., 121: 46-50

Parker, J. 1962 Relationships among cold hardiness, water soluble protein, anthocyanins and free sugars 
in IIederahelix: L. Pan Physiol., 37: 809-813

Rouseff, R. L. and S. Nagy 1982 Distribution of limonoids in citrus seeds. Phytochemistry, 21(1): 85-90

Sakai, A. 1960 Relation of sugar content to frost,-hardiness in plants. Nature, 185(4714): 698-699

Sakai, A. 1966 Studies of frost hardiness in woody plants. II. Effect of temperature on hardening. Plant Physiol., 41: $m-359$

Shiraishi, M. 1993 Three descriptors for sugars to evaluate grape germplasm. Euphytica, 71: 99-106

Sieckmann, S. and A. A. Boe 1978 Low temperature increases reducing and total sugar concentrations in leaves of Boxwood (Buxus sempernirens L.) and Cranberry (Vaccinium macrocarpon Ait.) Hortscience, 13(4): 439-440

Siminovitch, D., C. M. Wilson and D. R. Briggs 1953 Studies on the chemistry of the living bark of the Black Locus in relation to its frost hardiness. V. Seasonal transformations and variations in the carbohydrates: starch-sucrose interconversions. Plant Physiol., 28: 383-400

Sinclair, W. B. 1972 The Grapefmit. Its Composition, Plyssiology, and Product. Univ. of Calivornia, Div. of Agric. Sci., USA. 660pp

Sinclair, W. B. 1984 The Biochemistryand Physiology of the Lemonand Other Citrus Fruits. Univ. of California, Div. of Agric. and Nat. Res., USA. 946pp

Stommel, J. R. 1992 Enzyrnic components of sucrose accumulation in the wild tomato species Lycopersicon perunianum. Plant Physiol., 99: 324-328

Stommel, J. R. and K. G. Haynes 1993 Genetic control of fruit sugar accumulation in a Lycopersicon esculentum X L. hirsutum cross. J.Amer. Sot. Hort.Sci., 118(6): 859-863

Stommel, J. R. and P. W. Simon 1989 Phenotypic recurrent selection and heritability estimates for total dissolved solids and sugar type in carrot. J.Amer. Soc. Hort.Sci., 114(4): 695-699

Waki, T. 1959 Chemical studies on the sudachi, Citrus sudachiHort. ex Shirai. Part III. Changes of the juice components according to the ripeness, and the detection of sugars by the paper partition chromatography. Eizố to shokuryô,11(5):37-40 (in Japanese, with English summary)

Waki, T. and J. Nakanishi 1967 Chemical studies on the sudachi. Part IV. Perfume constituents of the sudachi fruit. Memoirs of Fac of Education, TokushimaUninersity, 27: 1-10

Wutscher, II. K. 1976 Influence of night temperature and daylength on fruit shape of grapefruit. J.Amer. Soc Hort.Sci., 101: 573575

Yamaki, Y. T. 1988 Differences in juice acidities of citrus species and relationships among acidities, and of acidities to potassium concentration. J.Japan.Soc.Hort.Sci, 56(4): 457-469 (in Japanese, with English summary)

Yamauchi, N., F. Hashinaga and S.Itoo 1991 Chlorophyll degradation with degreening of Kabosu (Citrus sphaterocaipa Hort. ex Tanaka) fruits. J.Japan.Soc. Hort.Sci., 59(4): 869-875

Yelle, S., J. D. Hewitt, N. L. Robinson, S. Damon, and A. B. Bennett 1988 Sink metabolism in tomato fruit. III. Analysis of carbohydrate assimilation in a wild species. Plant Plysiol., 87: 737-740

Yelle, S., R. T. Chetelat, M. Dorais, J. W. DeVerna and A. B. Bennett 1991 Sink metabolism in tomato fruit. IV. Genetic and biochemical analysis of sucrose accumulation. PlantPhysiol., 95: 1026-1035 